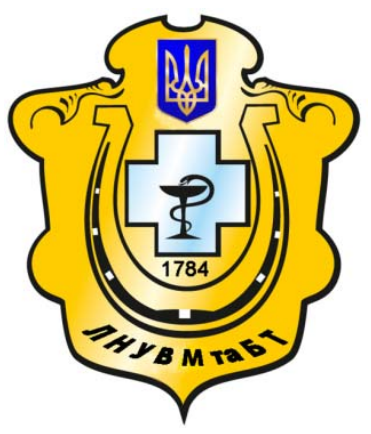

Науковий вісник Львівського національного університету ветеринарної медицини та біотехнологій імені С.3. Гжицького

Scientific Messenger of Lviv National University of Veterinary Medicine and Biotechnologies named after S.Z. Gzhytskyj

doi:10.15421/nvlvet7126

ISSN 2413-5550 print

ISSN 2518-1327 online

$\underline{\text { http://nvlvet.com.ua/ }}$

УДК 619:612.017:636.4

\title{
Функціонування імунного бар'єру кишечника поросят за дії технологічного стресу
}

\author{
В.Г. Стояновський, М.Т. Огродник \\ kolviktor1980@gmail.com
}

\begin{abstract}
Львівський наџіональний університет ветеринарної медицини та біотехнологій імені С.3. Гжицького, вул. Пекарська, 50, м. Львів, 79010, Україна
\end{abstract}

У статті наведено результати дослідження функціонального стану імунних структур кишечника поросят промислового вирощування до та після дії технологічного стресу-відлучення. Виявлено, щзо в тонких кишках поросят до та після відлучення функиіонує одна масивна єюно-ілеальна пейєрова бляшка, а також дрібні пейєрові бляшки. В структурі єюноілеальної пейєрової бляшки поросят 28-добового віку (до відлучення) на макроскопічному рівні виділяються окремі вузлики (куполоподібні), які інтенсивно фарбуються та чітко розрізняються, особливо у каудальній частині, що може вказувати на виражену реактивність лімфоїдної тканини, яка формує їх основу. На стадії резистентності (через 30 діб після відлучення) в структурі єюно-ілеальної пейєрової бляшки поросят на макроскопічному рівні куполоподібні вузлики щільно розтамовуються, тому вільних не профарбованих полів не реєструється. На гістологічному рівні в єюно-ілеальній пейєровій бляшиі поросят до відлучення реєструються первинні та вторинні вузлики з реактивними центрами розмноження, що $\epsilon$ ознакою повної морфофункиіональної зрілості лімфоїдної тканини, тоді коли в поросят після відлучення вторинних вузликів виявлялося значно менше, у деяких з них не має чітко сформованої оболонки, що може вказувати на гальмування розвитку імунних реакцій в межах лімфоїдної тканини слизової оболонки ШКТ чи про розвиток імунодефіцитного стану клітинного імунітету внаслідок дії стресу відлучення.

Ключові слова: імунна система, лімфоїдна тканина, пейєрові бляшки, лімфоїдні вузлики, тонкі та товсті кишки, поросята, відлучення, стрес, адаптація.

\section{Функциионирование иммунного барьера кишечника поросят за действия технологического стресса}

\author{
В.Г. Стояновский, М.Т. Огродник \\ kolviktor1980@gmail.com
}

\begin{abstract}
Львовский национальный университет ветеринарной медицины и биотехнологий имени С.3. Гжицкого, ул. Пекарская, 50, г. Львов, 79010, Украина
\end{abstract}

В статье приведены результаты исследования функиионального состояния иммунных структур кишечника поросят промышленного выращивания до и после воздействия технологического стресса-отъема. Выявлено, что в тонком кишечнике поросят до и после отъема функиионирует одна массивная еюно-илеальная пейеровая бляшка, а также мелкие пейеровые бляшки. В структуре еюно-илеальной пейеровой бляшки поросят 28-дневного возраста (до отъема) на макроскопическом уровне выделяются отдельные узелки (куполообразные), которые интенсивно окрашиваются и четко различаются, особенно в каудальной части, что может указывать на выраженную реактивность лимфоидной ткани, которая формирует их основу. На стадии резистентности (через 30 суток после отъема) в структуре еюно-илеальной пейеровой бляшки поросят на макроскопическом уровне куполообразные узелки плотно располагаются, поэтому не прокрашенных полей не регистрируется. На гистологическом уровне в еюно-илеальной пейеровой бляшкки поросят до отъема регистрируются первичные и вторичные узелки с реактивными центрами размножения, что является признаком полной морфофункциональной зрелости лимфоидной ткани, тогда как в поросят после отъема вторичных узелков оказывалось значительно меньше, в некоторых из них не имеет четко сложивщейся оболочки, что может указывать на торможение развития иммун-

Stojanovskyj, V.G., Ogrodnyk, M.T. (2016). Function of intestinal immune barrier of piglets under technological stress. Scientific Messenger LNUVMBT named after S.Z. Gzhytskyj, 18, 3(71), 112-116. 
ных реакиий в пределах лимфоидной ткани слизистой оболочки ЖКТ или о развитии иммунодефицита клеточного иммунитета вследствие действия стресса отьема.

Ключевые слова: иммунная система, лимфоидная ткань, пейеровые бляики, лимфоидные узелки, тонкий кишечник, толстый кишечник, поросята, отъем, стресс, адаптация.

\title{
Function of intestinal immune barrier of piglets under technological stress
}

\author{
V.G. Stojanovskyj, M.T. Ogrodnyk \\ kolviktor1980@gmail.com \\ Lviv National University of Veterinary Medicine and Biotechnologies named after S.Z. Gzhytskyi, \\ Pekarska Str., 50, Lviv, 79010, Ukraine
}

\begin{abstract}
The article presents the results of the study of the functional state structures intestinal immune piglets growing industrial and post-action process stress-weaning. It was established that the small intestine of piglets before and after weaning operates a big yeyuno-ileal Peyer's patche and small Peyer's patches. The structure of yeyuno-ileal Peyer's patche of pigs 28-day age (weaning) at the macroscopic level allocated separate nodules that are intensely stained and clearly different, especially in the caudal part that can point to a marked reactivity of lymphoid tissue that forms their basis. At the stage of resistance (30 days after weaning) in the structure of yeyuno-ileal Peyer's patche of pigs at the macroscopic level dome-shaped nodules are tight, so no free fields are not registered. At the histological level of yeyuno-ileal Peyer's patche of piglets before weaning registered primary and secondary nodules with reactive centers of reproduction, which is a sign of complete morphofunctional maturity lymphoid tissue, whereas when the piglets after weaning secondary nodules turned out far less, some of them have clearly formed shell, which may indicate the inhibition of immune responses within mucosal lymphoid tissue of the gastrointestinal tract or the development of immunodeficiency state of cellular immunity as a result of the stress of weaning.
\end{abstract}

Key words: immune system, lymphoid tissue, Peyer's patches, lymphoid nodules, small and large intestine, piglets, weaning, stress, adaptation.

\section{Вступ}

Рентабельність ведення галузі свинарства обумовлена високим генетичним потенціалом сучасних порід свиней за відгодівельними і м'ясними якостями. Проте, впродовж вирощування та експлуатації організм поросят постійно пристосовується до різних стресових факторів, з яких найбільш несприятливим є відлучення від свиноматки, що знижує продуктивність, збереженість поголів'я та економічну ефективність їх вирощування (Snitynskyi et al., 2002; Chumachenko, 2007). Як відомо, механізмом, що забезпечує адаптацію організму тварин до дії стрес-факторів лежить тісний функціональний зв'язок гіпоталамогіпофізарно-надниркової системи (Snitynskyi et al., 2002; Chumachenko, 2007; Stoianovskyi et al., 2013). Крім цього, значний вплив на адаптаційні процеси в організмі тварин має тип вищої нервової діяльності, зрівноваження процесів збудження і гальмування та стан імунологічної реактивності організму (Maslianko, 1999; Karpovskyi et al., 2012). При цьому, імунологічна адаптація розглядається на сьогодні, як одна 3 визначальних форм пристосувальних реакцій організму тварин до мінливих умов зовнішнього середовища (Maslianko, 1999). В світлі сказаного зрозумілий підвищений останніми роками інтерес дослідників до функціонального стану центральних і периферичних органів імунної системи поросят за дії технологічного стресу (Stoianovskyi et al., 2013). Насамперед, це стосується імунних структур, асоційованих 3 слизовою оболонкою кишечника, оскільки шлунково-кишковий тракт (ШКТ) є першим бар'єром для кормових антигенів при зміні годівлі чи переході на новий тип живлення. Метою наших досліджень було з'ясувати функціональний стан периферичних органів імунної системи (імунних структур кишечника) поросят промис- лового вирощування до та після дії технологічного стресу-відлучення.

\section{Матеріал і методи досліджень}

Досліди проведені в умовах ННВЦ «Давидівський» Львівського національного університету ветеринарної медицини та біотехнологій імені С.3. Гжицького на клінічно здорових поросятах 1060-добового віку полтавської білої породи. Для досліджень була сформована група поросят у кількості 10 особин. У підсисний період поросята утримувалися під свиноматкою у спеціальних станках, мали постійний доступ до матері, а з 5-добового віку - вільний доступ до концентрованих кормів. Годівля тварин проводилась у відповідності 3 нормами для даного віку свиней. Технологічним стресом був фактор відлучення на 28 добу життя та переведення поросят на групове утримання зі зміною структури раціону першого періоду відгодівлі (дорощування). Матеріалом для досліджень слугували тонкі та товсті кишки разом із вмістом, які відбирали після легкого наркозу та декапітації у трьох тварин до відлучення (на 28 добу життя) та у трьох тварин через 30 діб після відлучення (58 доба життя, що відповідає стадії резистентності за Г. Сельє). У тонких та товстих кишках макроскопічно вивчали топографію та морфометрію пейєрових бляшок (ПБ) за методом Хелмана (Romeis, 1954). У місцях локалізації ПБ відбирали зразки тканин для виготовлення гістологічних препаратів, які фарбували гематоксилін-еозином (Horalskyi et al., 2005). Серединні поперечні гістозрізи переглядали на світловому мікроскопі Leica DM-2500 (Switzerland) при збільшенні - ок. $10^{\times}$, об. $5^{\times}, 10^{\times}, 20^{\times}$, $40^{\times}$. На гістологічних зрізах вивчали розташування лімфоїдних вузликів (ЛВ). Мікрофотографування гістопрепаратів здійснювали за допомогою цифрової 
камери Leica DFC450C та програмного забезпечення Leica Application Suite Version 4.4[Build:454] Leica Microsystems (Switzerland) Limited.

\section{Результати та їх обговорення}

Отримані результати макроскопічних досліджень підтверджують дані літератури про функціонування в тонких кишках поросят до та після відлучення поодиноких ЛВ, однієї довгої єюно-ілеальної ПБ, а також менших ПБ (Stoianovskyi et al., 2013). Виявлено, що в поросят 28-добового віку (до відлучення) довжина єюно-ілеальної ПБ складала $115,40 \pm 10,11 \mathrm{~cm}$, а через 30 діб після відлучення ii довжина збільшувалася до $130,53 \pm 15,03$ см. За своєю структурою та формою єюно-ілеальна ПБ поросят 28- та 58-добового віку була схожою, починалася в каудальній частині порожньої кишки і продовжувалася у клубовій кишці. В структурі єюно-ілеальної ПБ поросят 28-добового віку на макроскопічному рівні виділялися окремі вузлики (куполоподібні), які інтенсивно фарбувалися та чітко розрізнялися, особливо у каудальній частині,

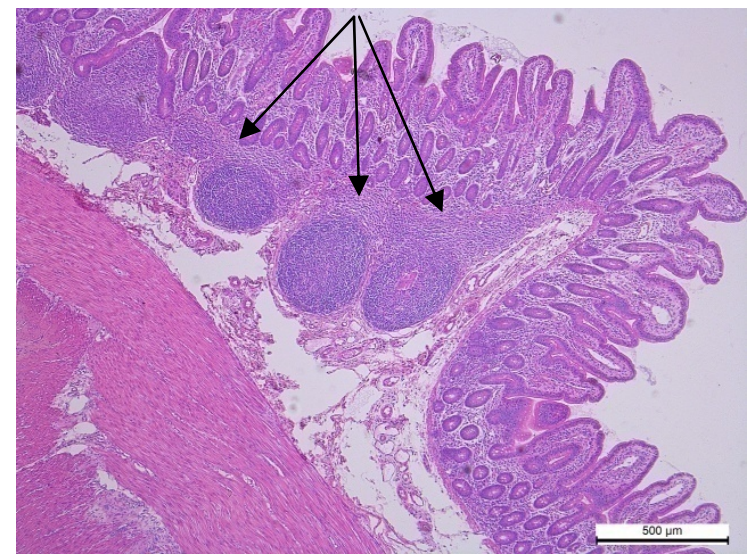

Рис. 1. Краніальна частина сюно-ілеальної ПБ поросят до відлучення. Первинні та вторинні ЛВ. Ок. $10^{\times}$, об. $5^{\times}$.

У каудальній частині єюно-ілеальної ПБ поросят до відлучення на гістозрізах виявлялися лімфоїдні вузлики (первинні і вторинні), щільно заповнені клітинами лімфоїдного ряду (рис. 3). Вони розташовувалися як у власній пластинці, так і у підслизовій основі слизової оболонки, були витягнутої форми; над вузликами виявлялися невисокі ворсинки. На серединних гістозрізах їх загальна кількість складала 19,20 \pm 4,31 шт. Первинні вузлики були оточені оболонкою 3 ретикулярних та колагенових волокон, що могло свідчити про завершення їх морфогенезу. (рис. 4). Отримані результати стосовно первинних i вторинних вузликів могли вказувати на повну морфофункціональну зрілість лімфоїдної тканини, асоційованої зі слизовою оболонкою кишечника поросят 28-добового віку що могло вказувати на виражену реактивність лімфоїдної тканини, яка формує їх основу. На стадії резистентності (через 30 діб після відлучення) в структурі єюно-ілеальної ПБ поросят на макроскопічному рівні куполоподібні вузлики щільно розташовувалися, тому вільних не профарбованих полів не реєструвалося. Кількість менших дрібних ПБ у тонких кишках поросят до та після відлучення становила відповідно $15,40 \pm 2,78$ шт та 21,70 $\pm 1,90$ шт. вони реєструвалися у клубовій кишці після єюно-ілеальної ПБ.

На мікроскопічному рівні у структурі єюноілеальної ПБ поросят до відлучення реєстрували ЛВ на різних етапах розвитку та дифузну лімфоїдну тканину, яка заповнювала простори між ними. У краніальній частині ПБ, яка розташовувалася в порожній кишці, виявлялися первинні та вторинні лімфоїдні вузлики (рис. 1 і рис. 2). На серединних гістозрізах їх

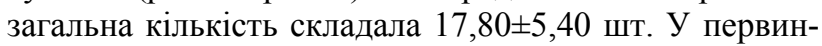
них вузликах не виявлялися світлі (гермінативні) центри, тоді коли у вторинних ЛВ такі центри були наявні (рис. 2).

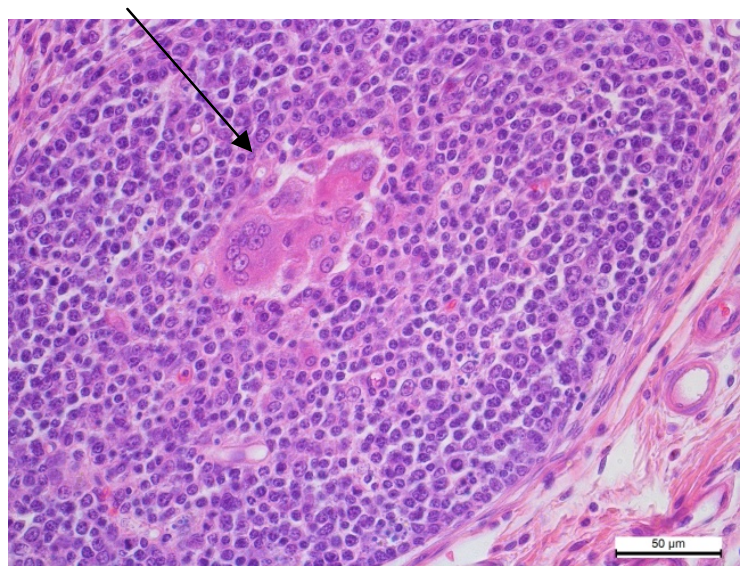

Рис. 2. Вторинний ЛВ з світлим центром у сюноілеальній ПБ поросят до відлучення. Ок. $10^{\times}$, об. $40^{\times}$.

У каудальній частині єюно-ілеальної ПБ поросят після відлучення на гістозрізах також реєструвалися лімфоїдні вузлики, щільно заповнені клітинами лімфоїдного ряду (рис. 5). Проте, вторинних вузликів виявлялося значно менше, у деяких 3 них не було чітко сформованої оболонки (рис.6). Виявлено, що клітинні елементи у складі вторинних ЛВ заповнювали епітеліальний шар слизової оболонки, а також проміжки між вузликами, внаслідок чого вузлики втрачали свою форму. Зміни у структурі вузликів поросят через 30 діб після відлучення можуть вказувати на гальмування розвитку імунних реакцій в межах лімфоїдної тканини слизової оболонки ШКТ чи про розвиток імунодефіцитного стану клітинного імунітету внаслідок відповідної реакції кори надниркових залоз на дію стресу відлучення. 


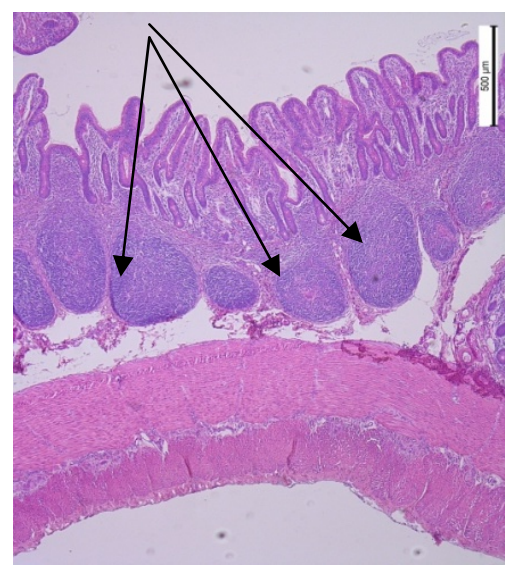

Рис. 3. Каудальна частина єюно-ілеальної ПБ поросят до відлучення. Первинні та вторинні ЛВ. Ок. $10^{\times}$, об. $5^{\times}$.

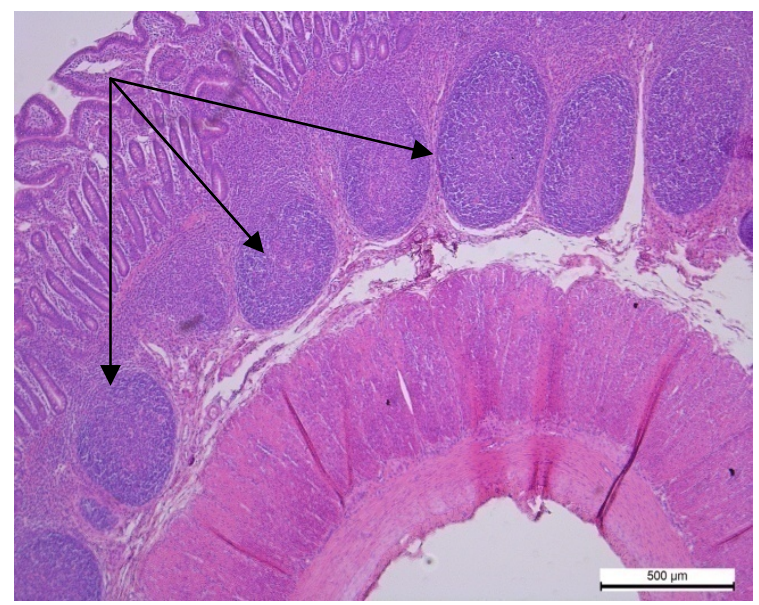

Рис. 5. Каудальна частина єюно-ілеальної ПБ поросят після відлучення. Первинні ЛВ. Ок. $10^{\times}$, об. $5^{\times}$.

У каудальній частині єюно-ілеальної ПБ поросят до та після відлучення відмічали формування первинних вузликів 3 передвузликових форм (рис. 7, 8), проте цей процес в ПБ поросят через 30 діб після відлучення характеризувався зниженою активністю, на що



Рис. 7. Каудальна частина сюно-ілеальної ПБ поросят до відлучення. Формування первинних ЛВ. Ок. $10^{\times}$, об. $40^{\times}$.

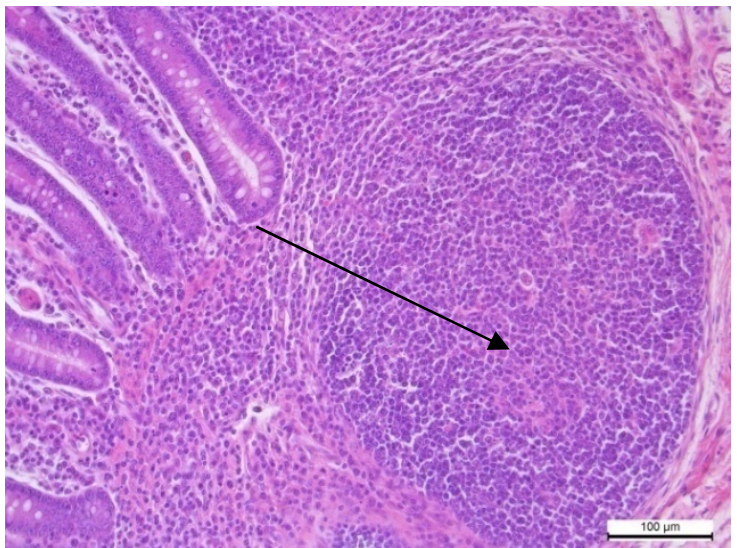

Рис. 4. Первинний ЛВ у складі єюно-ілеальної ПБ поросят до відлучення. Ок. $10^{\times}$, об. $20^{\times}$.



Рис. 6. Вторинний ЛВ у складі єюно-ілеальної ПБ поросят після відлучення. Ок. $10^{\times}$, об. $20^{\times}$.

вказує порівняно невелика форма вузликів та відсутність чітко сформованого обідка (рис.8).

В ободовій кишці (низхідне та висхідне коліно) поросят до та після відлучення при гістологічному дослідженні поодиноких ЛВ виявлено не було.

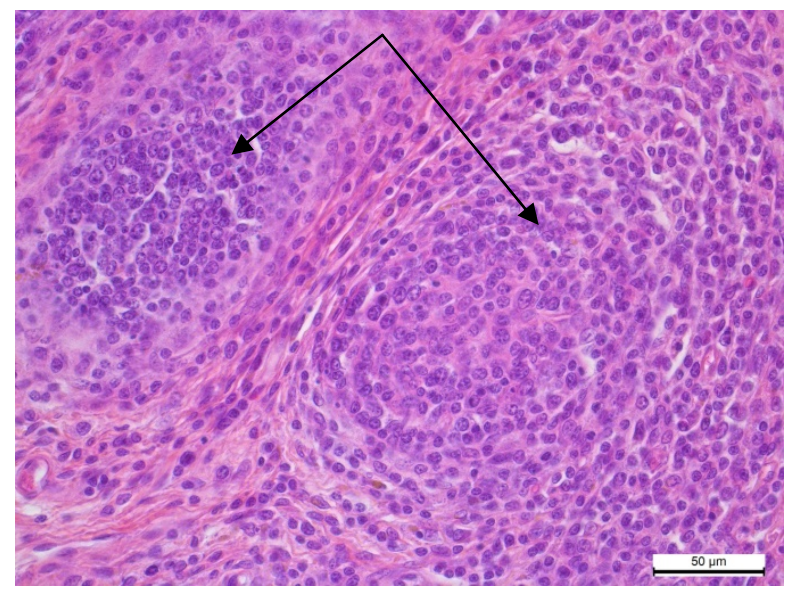

Рис. 8. Каудальна частина сюно-ілеальної ПБ поросят після відлучення. Формування первинних ЛВ. Ок. $10^{\times}$, об. $40^{\times}$. 


\section{Висновки}

1. Виявлено різницю у довжині єюно-ілеальної ПБ поросят, яка на 28 добу життя (до відлучення) становить $115,40 \pm 10,11 \mathrm{~cm}$, а через 30 діб після відлучення (58 доба життя) - 130,53 $\pm 15,03$ см. Кількість дрібних ПБ на різних стадіях досліду становить відповідно $15,40 \pm 2,78$ шт і 21,70 $\pm 1,90$ шт.

2. До відлучення поросят в структурі єюноілеальної ПБ реєструються первинні та вторинні вузлики з реактивними центрами розмноження, а через 30 діб після відлучення поросят виявляється значно менше вторинних вузликів без чітко сформованої оболонки.

Перспективи подальших досліджень. У подальшому планується дослідження функціонального стану периферичних органів імуногенезу поросят за дії стресу при використанні імунокоректорів.

\section{Бібліографічні посилання}

Horalskyi, L.P., Khomych, V.T., Kononskyi, O.I. (2005) Osnovy histolohichnoi tekhniky i morfofunktsionalni metody doslidzhennia $\mathrm{u}$ normi ta pry patolohii. Zhytomyr: «Polissia» (in Ukrainian).
Karpovskyi, V.I. Trokoz, V.O., Kryvoruchko, D.I., Trokoz, A.V., Shesterynska, V.V., Vasyliv, A.P. (2012). Umovno-reflektorna diialnist (povedinka) svynei riznykh typiv vyshchoi nervovoi diialnosti. Naukovi dopovidi Natsionalnoho universytetu bioresursiv i pryrodokorystuvannia Ukrainy. 8(30). Rezhym dostupu: http://nd.nubip.edu.ua/2012_1/ 12kvi.pdf. (in Ukrainian).

Maslianko, R.P. (1999). Osnovy imunolohii. Lviv: Vertykal (in Ukrainian).

Romeis, B.V. (1954). Mykroskopycheskaia tekhnyka. M.: Yzd. (in Russian).

Snitynskyi, V.V., Shakh, A.Ie., Iskra, R.Ia., Mykytyn, Iu.V. (2002). Vplyv tekhnohennoho stresu na fiziolohichnyi stan tvaryn i aktyvnist antyoksydantnoi systemy. Fiziol. zhurn. 48(2), 191-196.

Stoianovskyi, V.H. Matsiuk O.I., Kolomiiets I.A. (2013). Shliakhy pidvyshchennia adaptatsiinykh mozhlyvostei orhanizmu porosiat $\mathrm{v}$ umovakh tekhnolohichnoho stresu. Silskyi hospodar. Lviv. 11-12, 21-25 (in Ukrainian).

Chumachenko, V.V. (2007). Biokhimichni ta imunolohichni osnovy systemy profilaktyky stresu $\mathrm{v}$ svynei : avtoref. dys. ... d-ra vet. nauk : 03.00.04ю (in Russian).

Стаття надійшла до редакиї 27.09.2016 